\title{
Effects of therapeutic ultrasound on the retention and maintenance of the antioxidant activity of the glycolic extract of Arnica montana: an in vitro study
}

\author{
Efeito do Ultrassom Terapêutico sobre a retenção e manutenção da atividade \\ antioxidante
}

\author{
Paula Bianchetti ${ }^{1}$,João Fioravante Tassinary ${ }^{2}$, Simone Stülp ${ }^{* 3}$ \\ 1,2Centro de Ciências Biológicas e da Saúde, Centro Universitário Univates, Lajeado, Brasil \\ ${ }^{3}$ Doutora em Engenharia de Materiais, Centro Universitário Univates, Lajeado, Brasil
}

\begin{abstract}
The aim of the present study was to evaluate the retention of a glycolic extract of $A$. montana using a biomembrane model, and to determine the effect of therapeutic ultrasound on the antioxidant capacity of the extract. Biomembrane samples were treated in a vertical diffusion system with A. montana extract/hydrogel homogenate in the absence or presence of ultrasound ( $3 \mathrm{MHz} ; 1.0 \mathrm{~W} / \mathrm{cm} 2$ ). Biomembranes that had been submitted to ultrasound for 4 and 150 min retained, respectively, 93.5 and $69.03 \%$ less of the bioactive extract than those treated with passive diffusion for similar periods, thus indicating that phonophoresis enhances permeation through the membrane. Cyclic voltammetry was employed in the determination of antioxidant activities by measurement of the amount of hydrogen peroxide neutralized by the extract. Electrochemical analysis showed that the peak current related to the reduction of hydrogen peroxide diminished when extract was present. However, treatment of the extract with ultrasound gave rise to a decrease in the antioxidant potential, as indicated by an observed increase of $27 \%$ in hydrogen peroxide concentration in comparison with untreated extract. It is concluded that, although ultrasound improves permeation of the glycolic extract of $A$. montana, the antioxidant activity of the preparation is diminished.
\end{abstract}

Keywords: Drug delivery, Permeation, Ultrasound, Biomembrane retention, Antioxidant activity.

\section{Resumo}

TO objetivo do presente trabalho foi avaliar a retenção do extrato glicólico de A. montana usando biomembranas, além de determinar o efeito do ultrassom terapêutico sobre a capacidade antioxidante deste extrato. Amostras de biomembranas foram tratadas em célula de difusão vertical em presença de hidrogel contendo extrato de A. montana com e sem aplicação de ultrassom (3 MHz, $1 \mathrm{~W} / \mathrm{cm} 2$ ). Biomembranas foram submetidas ao ultrassom e analisadas, em termos de retenção de extrato, nos tempos de 4 e 150 min., sendo que a quantidade retida foi de 93.5 and $69.03 \%$ , respectivamente, indicando que a aplicação de US terapêutico promove o aumento de permeação de ativos. Ainda, a técnica de voltametria cíclica foi utilizada para avaliar a capacidade antioxidante do extrato de A. montana, sendo utilizados eletrodos impressos de Co-ftalocianina, indicando que, após a aplicação de ultrassom terapêutico, a capacidade antioxidante dos extratos foi diminuída. Desta forma, a partir do estudo realizado verificou-se que após aplicação do US terapêutico em extratos de A. montana, houve aumento da permeação do composto e diminuição de sua atividade antioxidante.

Palavras-chave: difusão de fármacos, permeação, ultrassom, retenção em biomembranas, atividade antioxidante.

* stulp@univates.br

Recebido: 12/03/2014 Aceito: 12/03/2014 


\section{Introduction}

$\mathrm{T}$ The use of antioxidant cosmetics in the protection of skin against the harmful effects of reactive oxygen species has increased substantially over recent years. For maximum efficiency, the active components in such preparations must be delivered to the inner layers of the skin by passage through the outermost layer (the stratum corneum), which is formed of dead cells (corneocytes) and functions as a barrier against infectious agents and dehydration (CHUONG et al., 2002). Although the transdermal administration of a drug affords various therapeutic advantages, topical formulations may require enhancement of permeation in order to be fully effective. Drug penetration can be enhanced chemically, by incorporating polyethylene glycol or glycerol trioleate in the formulation, or by physical methods such as electroporation or phonophoresis (BORGES, 2006). In the latter technique, therapeutic ultrasound is employed to loosen up the matrix of body tissues (the thixotropic effect), thereby making them more permeable to, mainly, anti-inflammatory and analgesic drugs. Phonophoresis typically involves the use of hydrogels as vehicles of drug delivery since they exhibit better conductivity and consistency in comparison with emulsions or oils (LOW \& REED, 2001; GUIRRO \& GUIRRO, 2002; BYL, 2012), and is possible to apply this technique at $1 \mathrm{MHz}$ and 3 $\mathrm{MHz}$, and cavitation and thermal processes are possible to occur, in different applied intensities (OMENA et al., 2012; O'BRIEN JR., 2007).

Arnica montana L. (Asteraceae) has been used in traditional Brazilian medicine in the form of tinctures, emulsions and creams for the treatment of pain and inflammation caused by bruising and edemas (BALME, 1982; D'AMELIO, 1999). The anti-inflammatory properties of this plant are attributed to the presence of sesquiterpene lactones, principally esters of helenalin and dihydrohelenalin (ALFREDO et al., 2008), while the antioxidant activity is associated with the presence of quercetin, caffeic acid and chlorogenic acid (PYTEL ET AL., 2005; GANZERA ET AL., 2008). The pharmaceutical use of A. montana has been authorized by the Brazilian National Health Surveillance Agency (Agência Nacional de Vigilância Sanitária, ANVISA) at concentrations equivalent to $0.20-0.25 \mathrm{mg} / \mathrm{mg}$ total sesquiterpene lactones for creams and ointments, and to $1 \mathrm{mg} / \mathrm{mL}$ total sesquiterpene lactones diluted 3 to 30 times for tinctures. The oral administration of high doses of preparations containing A. montana is contraindicated by virtue of their potential toxic effects, which may give rise to gastrointestinal problems and, in pregnant women, increased uterine motility and abortion (VEIGA-JUNIOR et al., 2005).

The application of phonophoresis with hydrogel containing A. montana extracts has been investigated with respect to the treatment of acute induced inflammation in experimental rats (ALFREDO et al., 2009). However, no studies have focused on the retention of the active principles of A. montana by the stratum corneum, a factor that is particularly important, since it is from this location that diffusion to the inner layers of the skin occurs. Additionally, assessment of the maintenance of the biological properties of the active principles during and after phonophoresis is also crucial since it is known that ultrasound can promote alterations in the properties of molecules (SALING et al., 2012; TASSINARY et al., 2011).

In consideration of the above, the objectives of the present study were: (i) to evaluate the retention of a glycolic extract of A. montana using an in vitro assay with a biomembrane model (shed snake skin), and (ii) to determine the effect of therapeutic ultrasound on the antioxidant capacity of the plant extract by means of electrochemical analysis.

\section{Methodology}

\subsection{Sample preparation}

A glycolic extract of A. montana (purchased from Importadora Química Delaware, Porto Alegre, RS, Brazil) was added to hydrogel (containing propylene glycol - Mercur; Santa Cruz do Sul, RS, Brazil) to a final concentration of $183 \mathrm{mg} \mathrm{L}-1$, and the mixture was homogenized using a Fisatom (São Paulo, SP, Brazil) model 703D mechanical stirrer.

\subsection{Retention of plant extract on a model bio- membrane}

The retention of A. montana extract was assessed using shed snake (Boa constrictor) skin, which constitutes a readily obtainable model biomembrane presenting a barrier similar to that of human stratum corneum (MEGRAB et al., 2005; HAIGH et al., 1998). These membranes was added in a diffusion cell (Franz cell), and the retention solution are water/ethyl alcohol 1:1. The biomembranes were treated for 4 and 150 min with $\mathrm{A}$. montana glycolic extract/hydrogel using a vertical diffusion system either with or without phonophoresis. In the first case, a DGM Eletrônica (Santo André, SP, Brazil) therapeutic ultrasound instrument was employed in the continuous mode at a frequency of $3 \mathrm{MHz}$ and an intensity of $1.0 \mathrm{~W} / \mathrm{cm} 2$, for $4 \mathrm{~min}$, in the diffusion cell with the biomembrane. This time is used to simulate the clinical application, and the second time (150 min.) is used to simulate after the therapeutic ultrasound in vivo situation. After treatment, the membranes were extracted with ethanol/water (1:1; v/v) for $40 \mathrm{~min}$ with sonication in a Unique (Indaiatuba, SP, Brazil) model USC 1450 ultrasonic bath, and the absorbance at $272 \mathrm{~nm}$ of this extract was recorded using a Varian Cary (Palo Alto, CA, USA) 100 Bio UV/Vis spectrophotometer. The amount of $\mathrm{A}$. montana extract that had been retained 
by the biomembrane was estimated on the basis of a calibration curve constructed in the concentration range 18.3 - $183 \mathrm{mg}$ L-1. All experiments were carried out in triplicate.

\subsection{Effect of phonophoresis on antioxidant activity of plant extract}

The effect of exposure to ultrasound on the antioxidant activity of the glycolic extract of A. montana was determined by cyclic voltammetry carried out in continuous mode at a frequency of $3 \mathrm{MHz}$ and a power density of $1.0 \mathrm{~W} / \mathrm{cm} 2$. The experiments were carried out using an Autolab (Ecochemie, Utrecht, The Netherlands) model PGSTAT128N potentiostat and DropSens (Oviedo, Spain) model DRP-410 screen-printed disposable electrodes. The three-electrode system comprised a $12.5 \mathrm{~mm} 2$ glassy carbon working electrode that had been chemically modified with cobalt phthalocyanine for increased sensitivity to hydrogen peroxide, a carbon counter electrode and a Ag/ $\mathrm{AgCl}$ quasi-reference electrode, all of which remained in contact with the hydrogel electrolyte. The potentials of the working and counter electrodes were expressed in relation to the quasi-reference electrode. Cyclic voltammograms were recorded at a scanning speed of $10 \mathrm{mV}$ s-1 with samples containing electrolyte and hydrogen peroxide p.a. (Quimis, Diadema, SP, Brazil; 162 mmol L-1) or electrolyte and hydrogen peroxide plus A. montana glycolic extract before and after ultrasound treatment. The concentration of hydrogen peroxide present in the system was determined from the peak voltammetric current by application of a calibration curve previously constructed in the concentration range $16-162 \mathrm{mmol}$ L-1. All experiments were carried out in triplicate.

\section{Results and discussion}

The proportion of A. montana glycolic extract retained by the model biomembrane (shed snake skin) in the absence or presence of phonophoresis was estimated spectrophotometrically. The best-fit linear equation for the calibration curve was $y=0.002044 x-0.01889$ (where $\mathrm{y}$ represents the absorbance at $272 \mathrm{~nm}$ and $\mathrm{x}$ the concentration of plant extract within the range 18.3 - $183 \mathrm{mg}$ L-1): the correlation coefficient (R2) was 0.9896 indicating a high degree of correlation between the variables.

As shown in Fig. 1, phonophoresis influenced the quantity of A. montana glycolic extract retained by the model biomembrane. Thus, after 4 and 150 min of exposure to diffusion with therapeutic ultrasound (the time of exposure to ultrasound was $4 \mathrm{~min}$ ), the amounts of extract retained by the biomembrane was reduced, respectively, to 93.5 and $69.03 \%$ of the values obtained following passive diffusion for similar periods. It is, therefore, concluded that phonophoresis enhances permeation of the extract through the membrane. Moreover, the length of exposure to the extract influenced permeation, since longer contact with the membrane resulted in lower amounts of extract being retained independent of the application of ultrasound.

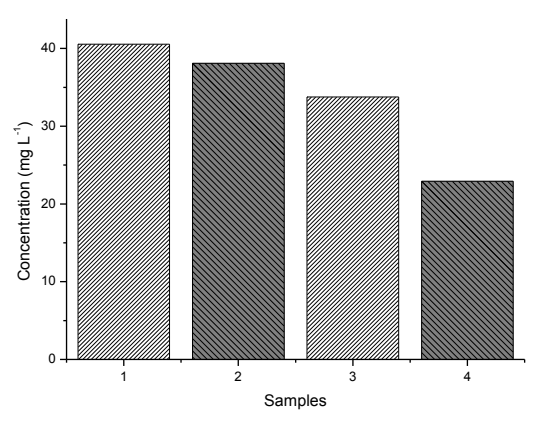

Fig. 1. Concentration of glycolic extract of Arnica montana retained from a hydrogel homogenate by a model biomembrane (snake skin) after 4 or $150 \mathrm{~min}$ in a vertical diffusion system without (bars 1 and 3 , respectively) or with (bars 2 and 4, respectively) phonophoresis.

It has been shown previously that application of ultrasound increases the permeability of membranes (MITRAGOTRI \& KOST, 2004), a phenomenon that is attributed to the formation and subsequent rupture of microbubbles inside the tissue, thereby modifying membrane ultrastructure (POLAT et al., 2011; POLAT et al., 2012; JESUS et al., 2006). For this reason, it is important to ensure that no lesions are present in the area of skin to be treated by phonophoresis, since modifications of the structure of the stratum corneum could facilitate the infiltration of inflammatory cells (ALFREDO et al., 2009). In such cases, the application of therapeutic ultrasound could give rise to a pro-inflammatory effect rather than the anti-inflammatory effect described in the literature. In the other hand, is possible to occur thermal effects, and in this case, the increase in release is also increased.

Phonophoresis may modify the structure of the active principles of the therapeutic agent which, in relation to the antioxidant properties of A. montana, are quercetin, caffeic acid and chlorogenic acid. Alterations in the antioxidant capacity of A. montana extract following phonophoresis could be demonstrated by monitoring the level of hydrogen peroxide present in the system before and after exposure to ultrasound using electrochemical analysis at a potential of $450 \mathrm{mV}$ (SERGEYEVA et al., 1999). In aerobic organisms, hydrogen peroxide is generated by the reduction of oxygen via the mitochondrial electron transport chain. Since hydrogen peroxide is a strong oxidant, reaction in vivo with biomolecules can result in harmful consequences within the body, including the induction of cancer and cardiovascular diseases (MATTOS et al., 2003; RAGNINI et al., 2001). 
In the present study, hydrogen peroxide was monitored using screen-printed carbon electrodes that had been chemically modified with cobalt phthalocyanine in order to provide a higher current response to the analyte (SERGEYEVA et al., 1999; CHAVE et al., 2003; OZOEMENA et al., 2005; ÇEKEN et al., 2012). As shown in Fig. 2, the peak current at $450 \mathrm{mV}$ related to the reduction of hydrogen peroxide diminished when $\mathrm{A}$. montana extract was present, indicating that the active principles of the extract were effective in neutralizing the oxidative effect of this molecule. Following the application of ultrasound, the antioxidant potential of A. montana extract apparently decreased, possibly as a consequence of the degradation of active principles by acoustic waves and cavitation effects (ROOZE et al., 2013; KOEKE et al., 2005). Previous studies have intimated the ultrasound-induced degradation of the anti-inflammatory principles present in A. montana (ALFREDO et al., 2009). Furthermore, the active principles of A. montana exhibited electroactive behavior in the studied potential range, producing voltammograms that were similar to those reported previously (REYES-SALAS et al., 2002).

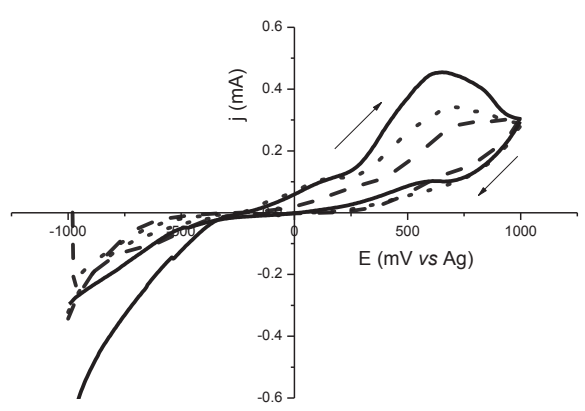

Fig.2. Cyclic voltammograms showing the current responses of hydrogel containing $162 \mathrm{mmol} \mathrm{L}-1$ of hydrogen peroxide (-), and hydrogel/hydrogen peroxide plus A. montana glycolic extract before $(---)$ and after $(\bullet \bullet \bullet)$ application of therapeutic ultrasound. The experiments at using screen-printed carbon electrodes chemically modified with cobalt phthalocyanine and a scanning speed of $10 \mathrm{mV} \mathrm{s}-1$.

The quantitative determination of hydrogen peroxide was achieved using a calibration curve, the best-fit linear equation of which was $y=2.46631 \mathrm{E}-6 \mathrm{x}+5.55198 \mathrm{E}-5$ (where $y$ represents the current and $x$ the concentration of hydrogen peroxide within the range $16-162 \mathrm{mmol}$ L-1): the value of R2 was 0.9846 indicating a high degree of correlation between the variables. Analysis revealed that the concentration of hydrogen peroxide present in the system containing the glycolic extract of A. montana extract to which ultrasound had not been applied was $89.31 \mathrm{mmol} \mathrm{L}-1$, a value that was $21 \%$ lower than that (113.35 mmol L-1) found in the system to which ultra- sound had been applied. These results demonstrate that therapeutic ultrasound indeed reduces the antioxidant effect of A. montana extract.

\section{Conclusions}

Although phonophoresis increased the permeation of glycolic extract of A. montana through a biomembrane (as shown by the reduced retention of the extract by the snake skin model), the application of ultrasound exerted a negative effect on the antioxidant capacities of the active principles. Electrochemical analyses revealed that when extract samples were exposed to acoustic waves, the capacity to remove hydrogen peroxide from the system diminished by more than $21 \%$. Hence, it is important to prevent the degradation of A. montana extracts and preserve the bioactivity by employing carrier systems such as liposomes, niosomes, micro- or nano-spheres. Moreover, further studies are required to investigate delivery systems that are biocompatible with the skin lipid bilayer and, at the same time, with the acoustic waves applied in order to facilitate permeation through the stratum corneum.

\section{Acknowledgements}

The authors wish to thank Fundação de Amparo à Pesquisa do Estado do Rio Grande do Sul (FAPERGS) for financial support.

\section{References}

Agência Nacional de Vigilância Sanitária, Legislação em Vigilância Sanitária, Resolução no. 89 de 16 de março de 2004: Lista de Registro Simplificado de Fitoterápicos, Diário Oficial da União, Brasília, 2004. http://www.anvisa.gov.br

Alfredo, P. P.; Anaruma, C. A.; Pião, A. C. S.; João, S. M. A.; Casarotto, R. A. Análise qualitativa dos efeitos da sonoforese com Arnica montana sobre o processo inflamatório agudo do músculo esquelético de ratos, Fisioter. Pesq. 3 (2008) 273-279.

Alfredo, P. P.; Anaruma, C. A.; Pião, A. C.; João, S. M.; Casarotto, R. A. Effects of phonophoresis with Arnica montana onto acute inflammatory process in rat skeletal muscles: an experimental study, Ultrasonics 49 (2009) 466-471.

Balme, F. Plantas Medicinais, Hemmus, São Paulo, 1982. 
Borges, F. S. Dermato-funcional: Modalidades Terapêuticas nas Disfunções Estéticas, Phorte, São Paulo, 2006.

Byl, N. N. The use of ultrasound as an enhancer for transcutaneous drug delivery: Phonophoresis, Phys. Ther. 75 (2012) 539-553.

Çeken, B.; Kandaz, M.; Koca, A. Electrochemical hydrogen peroxide sensor based on cobalt phthalocyanine captured in polyaniline film on a glassy carbon electrode, J. Porphyrins Phtalocyanines 16 (2012) 380-389.

Chave, J. A. P.; Araújo, M. F. A.; Varela-Júnior, J. J. G.; Tanaka, A. A. Eletrocatálise da reação de redução de oxigênio sobre eletrodos de grafite modificados com ftalocianina tetracarboxilada de ferro, Eclética Quím. 28 (2003) 9-19.

Chuong, C. M.; Nickoloff, B. J.; Elias, P. M.; Goldsmith, L. A.; Macher, E.; Maderson, P. A.; Sundberg, J. P.; Tagami, H.; Plonka, P. M.; Thestrup-Pedersen, K.; Bernard, B. A.; Schröder, J. M.; Dotto, P.; Chang, C.H.; Williams, M.L.; Feingold, K.R.; King, L. E.; Kligman, A. M.; Rees, J. L.; Christophers, E. What is the 'true' function of skin?, Exp. Dermatol. 11 (2002) 159-187.

D'Amelio, F. S. Botanicals: A Phytocosmetic Desk Reference, CRC Press, Boca Raton, 1999.

Ganzera, M.; Egger, C.; Zidorn, C.; Stuppner, H.; Quantitative analysis of flavonoids and phenolic acids in Arnica montana L. by micellar electrokinetic capillary chromatography, Anal. Chim. Acta 614 (2008) 196-200.

Guirro, E.; Guirro, R. Fisioterapia Dermato-funcional: Fundamentos, Recursos e Patologias, third ed., Manole, São Paulo, 2002.

Haigh, J. M.; Beyssac, E.; Chanet, L.; Aiacheet, J. M.; In vitro permeation of progesterone from a gel through the shed skin of three different snake species, Int. J. Pharm. 170 (1998) 151-156.

Jesus, G. S.; Ferreira, A. S.; Mendonça, A. C. Fonoforese x permeação cutânea. Fisioter. Mov. 19 (2006) 83-89.

Koeke, P. U.; Parizotto, N. A.; Carrinho, P. M. Salete, A. C. B. Comparative study of the efficacy of the topical application of hydrocortisone, therapeutic ultrasound and phonophoresis on the tissue repair process in rat tendons. Ultrasound Med. Biol. 31 (2005) 345-350.
Low, J.; Reed, A. Eletroterapia Explicada: Princípios e Prática, Manole, São Paulo, 2001.

Mattos, I. L.; Shiraishi, K. A.; Braz, A. D.; Fernandes, J. R. Peróxido de hidrogênio: importância e determinação. Quím. Nova 26 (2003) 373-380.

Megrab, N. A.; Williams, A. C.; Barry, B. W. Oestradiol permeation across human skin, silastic and snake skin membranes: the effects of ethanol/ water co-solvent systems, Int. J. Pharm. 116 (2005) 101-112.

Mitragotri, S.; Kost, J. Low-frequency sonophoresis. A review, Adv. Drug Deliv. Rev. 56 (2004) 589-601.

O’Brien Jr., W. D. Ultrasound-byophysics mechanisms, Progress in Biophysics and Molecular Biology, 93 (2007) 212-255.

Omena, T. P.; Costa, R. M.; Pereira, W. C. A.; Krüger, M. A. Calorímetro diferencial para estudo do padrão de aquecimento gerado por feixes ultrssônicos terapêuticos, Rev. Bras. Eng. Biom., v. 29, n. 4, p. 355-363, 2012.

Ozoemena, K. I.; Zhao, Z.; Nyokong, T. Immobilized cobalt(II) phthalocyanine-cobalt(II) porphyrin pentamer at a glassy carbon electrode: Applications to efficient amperometric sensing of hydrogen peroxide in neutral and basic media, Electrochem. Commun. 7 (2005) 679-684.

Polat, B. E.; Deen, W. M.; Langer, R.; Blankschtein, D. A physical mechanism of chemical penetration enhancer delivery into skin during low-frequency ultrasound treatment - insight into the observed synergism, J. Control. Release 158 (2012) 250-260.

Polat, B. E.; Hart, D.; Langer, R.; Blankschtein, D. Ultrasound-mediated transdermal drug delivery: mechanisms, scope, and emerging trends, J. Control. Release 152 (2011) 330-348.

Pytel, R. F.; Silva, L. V. N.; Nunes, A. S.; Gesztesi, J. L.; Costa, A. Estudo in vivo de atividade anti-radicalar por quantificação de peróxidos cutâneos. An. Bras. Dermatol. 80 (2005) 323-328.

Ragnini, C. A. R.; Di Iglia, R. A.; Bertazzoli, R. Considerações sobre a eletrogeração de peróxido de hidrogênio, Quím. Nova 24 (2001) 252-256.

Reyes-Salas, E. O.; Rangel-Ordonez, L.; ManzanillCano, J. A.; Barceló-Quintal, M. H.; Dosal-Gómez, M. A. Voltammetric determination of caffeic acid in Arnica montana, Anal. Lett. 35 (2002) 971-984. 
Rooze, J.; Rebrov, E. V.; Schouten, J. C.; Keurentjes,

J. T. F. Dissolved gas and ultrasonic cavitation - A review, Ultrason. Sonochem. 20 (2013) 1-11.

Saling, C.; Bianchetti, P.; Tassinary, J. A.; Ethur, E. M.; Stülp, S. Effects of therapeutic ultrasound on rutin, ECS Trans. 43 (2012) 97-101.

Sergeyeva, T. A.; Lavrik, N. V.; Rachkov, A. E.; Kazantseva, Z. I.; Piletsky, S. A.; El'skaya, A. V. Hydrogen peroxide-sensitive enzyme sensor based on pthalocyanine thin film, Anal. Chim. Acta 391 (1999) 289-297.

Tassinary, J. A.; Bianchetti, P.; Rempel, C.; Stülp, S. Avaliação dos efeitos do ultrassom terapêutico sobre a cafeína e verificação da liberação em sistema de difusão vertical, Quím. Nova 34 (2011) 1539-1543.

Veiga-Junior, V. F.; Pinto, A. C.; Maciel, M. A. M. Plantas medicinais: cura segura?, Quím. Nova 3 (2005) 519-528. 